\title{
Apple Root Growth, Turnover, and Distribution Under Different Orchard Groundcover Management Systems
}

\author{
Shengrui Yao \\ Department of Horticulture, North Central Research and Outreach Center, \\ University of Minnesota, Grand Rapids, MN 55744
}

Ian A. Merwin ${ }^{1}$ and Michael G. Brown

Department of Horticulture, Cornell University, 134 Plant Science, Ithaca, NY 14853

Additional index words. orchard floor management, Malus $\times$ domestica, minirhizotron, root biology, root mortality

\begin{abstract}
Minirhizotrons were used to study root emergence, turnover, and depth distribution of apple (Malus $\times$ domestica Borkh.) rootstocks (M.9/MM.111) under four groundcover management systems (GMSs) - pre-emergence herbicide (Pre-H), postemergence herbicide (Post-H), mowed sod grass (Grass), and hardwood bark mulch (Mulch) - that had been maintained since 1992 in an orchard near Ithaca, NY. Two root observation tubes were installed on both sides of one tree in three replicates for each GMS treatment. Roots were observed by camera at 2- to 3-weekly intervals during the growing seasons of 2002 and 2003 and from whole tree excavations in Apr. 2000. Tree growth and yield observations from 1992 to 2003 showed that Mulch and Post-H treatments produced more tree growth and higher yields than other treatments during most years; the Grass treatment usually had the smallest trees and lowest yields. More root emergence was observed in a light crop year (2002) than in a heavy crop year (2003). Pre-H treatment trees had more total roots and new roots than all other treatments, and trees in Grass plots had fewer total roots than others. Trees in Mulch plots had more shallow roots, and trees in Grass plots had more deep roots than others. Root diameter was positively correlated with overwintering root survival. The Pre-H treatment trees had greater root mortality than other trees during an unusually hot and dry growing season (2002) and this was attributed to higher shallow soil temperatures in this treatment. The GMS treatments affected root number and root depth distribution patterns. Despite microsprinkler irrigation, hot, dry weather conditions coincided with decreased root growth, increased root mortality, and reduced root median lifespan. GMS treatments affected root growth, turnover, and distribution at this orchard, and these differences were linked with long-term trends in tree growth and fruit production in this study.
\end{abstract}

Orchard floor and groundcover management is an important issue for fruit growers, affecting the ease of orchard operation as well as tree performance and soil quality. Herbicide-treated tree rows with mowed grass drive lanes are the most widely used orchard groundcover management systems (GMS) in North America and Europe, and this system is usually the most efficient and least expensive to maintain (Hogue and Neilsen, 1987; Merwin, 2003). However, with increased environmental concerns about the impact of herbicides and mechanical soil tillage, alternative methods are needed to suppress orchard weeds and maintain soil quality. Different mulches (biomass, inorganic, and geotextile) and cover crops have been widely tested (Goh et al., 2001; Merwin et al., 1996; Tworkoski and Glenn, 2001;

Received for publication 1 July 2008. Accepted for publication 23 Oct. 2008.

${ }^{1}$ To whom reprint requests should be addressed; e-mailim13@cornell.edu. petition and that smaller roots were less affected. Most root studies in GMS experiments have relied on destructive root excavations or trench transect observations to provide information about root distribution, density, and biomass partitioning, horizontally and vertically. However, destructive root excavation does not provide reliable information about fine root lifecycle or turnover.

Minirhizotron observation tubes enable researchers to observe the same roots repeatedly in situ with minimal disturbance and provide information about root lifecycle, distribution, diameter, and length (Hendrick and Pregitzer, 1992; Reid et al., 1993). Minirhizotron root study also has serious limitations; it involves primarily fine roots and samples a very small portion of the total root system, which increases sample variance and limits statistical differentiation among treatments (Eissenstat and Yanai, 1997; Yao et al., 2006). Despite these limitations, minirhizotron techniques have provided useful information about the timing and extent of root turnover in perennial fruit crops (Eissenstat et al., 2000; Psarras et al., 2000; Wells and Eissenstat, 2001; Wells et al., 2002).

The present experiment involved minirhizotron observations of apple roots after 10 years in a long-term comparison of different GMSs established in 1992 and maintained continuously since that time. Tree growth, yield, nutrient uptake, retention and leaching, soil moisture content, and soil temperature data have been collected annually in this study and differ substantially among the GMS treatments (Merwin, 2003). Effects on soil physical properties, replant disease severity, and soil microbial community observations from this study have been reported elsewhere (Oliveira and Merwin, 2001; Yao et al., 2005). Root systems obviously play an important role in tree growth and development, but little is known about differential GMS effects on orchard root growth and distribution. The present study compared apple root density and distribution, root turnover, and root lifespan of trees after 10 years under different GMS treatments using whole-tree excavations and minirhizotron observations during several growing seasons.

\section{Materials and Methods} 2003b; Pedersen, 1997), whereas only a few studies have investigated how GMSs affect root growth. Atkinson and White (1976) reported that most apple root growth occurred in the herbicide strip under trees. Parker et al. (1993) and Parker and Meyer (1996) reported that peach (Prunus persica L.) root density and root distribution were affected by orchard floor management. Stefanelli and Perry (2006) reported increased shallow root frequency in trench observations of apple trees in mulch and flame weeding treatments compared with mechanical cultivation. In a greenhouse study of containergrown trees, Glenn and Welker (1989) indicated that only roots with diameters greater than $1 \mathrm{~mm}$ were influenced by tall fescue (Festuca arundinacea L.) groundcover com-
Orchard site and groundcover management system treatments. Apple trees (cv. Empire on M.9/MM.111 interstem rootstocks) were planted at 3-m (within row) by 6-m (between rows) spacing in Apr. 1992 at a site on the east shore of Cayuga Lake near Ithaca, NY (Merwin et al., 1996). Three replications of four GMS treatments were established in 1992 and have been maintained since that time in 2-m wide tree-row strips: 1) Pre-H: pre-emergence herbicide treatment of glyphosate (N-phosphonomethyl glycine), norflurazon, and diurontank-mixed at $2.0,3.0$, and $2.5 \mathrm{~kg} \cdot \mathrm{ha}^{-1}$ a.i., respectively, and applied in mid-May each year; 2) Post-H: postemergence herbicide 
Table 1. Total root counts, new roots, and dead roots of trees under four groundcover management system (GMS) treatments during 2002 and 2003.

\begin{tabular}{|c|c|c|c|c|c|c|c|}
\hline \multicolumn{4}{|c|}{2002} & \multicolumn{4}{|c|}{2003} \\
\hline & $\begin{array}{l}\text { Total } \\
\text { roots }\end{array}$ & $\begin{array}{l}\text { New } \\
\text { roots }\end{array}$ & $\begin{array}{l}\text { Dead } \\
\text { roots }\end{array}$ & & $\begin{array}{l}\text { Total } \\
\text { roots }\end{array}$ & $\begin{array}{l}\text { New } \\
\text { roots }\end{array}$ & $\begin{array}{l}\text { Dead } \\
\text { roots }\end{array}$ \\
\hline \multicolumn{4}{|c|}{ GMS treatment effects } & \multicolumn{4}{|c|}{ GMS treatment effects } \\
\hline Pre-H & $18.6 \mathrm{a}$ & $2.15 \mathrm{a}$ & $9.12 \mathrm{a}$ & Pre-H & $13.07 \mathrm{a}$ & $1.58 \mathrm{a}$ & $3.71 \mathrm{a}$ \\
\hline Mulch & $15.6 \mathrm{~b}$ & $1.67 \mathrm{ab}$ & $5.57 \mathrm{~b}$ & Post-H & $11.78 \mathrm{~b}$ & $1.26 \mathrm{ab}$ & $3.66 \mathrm{a}$ \\
\hline Post-H & $13.6 \mathrm{c}$ & $1.31 \mathrm{~b}$ & $4.37 \mathrm{c}$ & Grass & $8.02 \mathrm{c}$ & $0.97 \mathrm{~b}$ & $2.78 \mathrm{~b}$ \\
\hline Grass & $9.3 \mathrm{~d}$ & $1.42 \mathrm{ab}$ & $2.87 \mathrm{c}$ & Mulch & $7.22 \mathrm{~d}$ & $1.06 \mathrm{~b}$ & $2.47 \mathrm{~b}$ \\
\hline \multicolumn{4}{|c|}{ Time effects } & \multicolumn{4}{|c|}{ Time effects } \\
\hline 21 June 2002 & $6.00 \mathrm{a}$ & & & 8 May 2003 & $5.14 \mathrm{a}$ & & \\
\hline 5 July 2002 & $9.71 \mathrm{~b}$ & $3.71 \mathrm{a}$ & $0.13 \mathrm{a}$ & 3 June 2003 & $6.64 \mathrm{~b}$ & $1.50 \mathrm{a}$ & $0.42 \mathrm{a}$ \\
\hline 19 July 2002 & $10.50 \mathrm{~b}$ & $0.88 \mathrm{~cd}$ & $0.83 \mathrm{~b}$ & 25 June 2003 & $8.32 \mathrm{c}$ & $1.68 \mathrm{a}$ & $0.82 \mathrm{a}$ \\
\hline 2 Aug. 2002 & $13.08 \mathrm{c}$ & $2.38 \mathrm{ab}$ & $3.17 \mathrm{c}$ & 20 July 2003 & $9.99 \mathrm{~d}$ & $1.67 \mathrm{a}$ & $2.17 \mathrm{~b}$ \\
\hline 16 Aug. 2002 & $13.83 \mathrm{cc}$ & $0.88 \mathrm{~d}$ & $3.54 \mathrm{c}$ & 14 Aug. 2003 & $11.45 \mathrm{e}$ & $1.46 \mathrm{ab}$ & $3.20 \mathrm{c}$ \\
\hline 30 Aug. 2002 & $16.17 \mathrm{de}$ & $2.33 \mathrm{bc}$ & $4.96 \mathrm{~d}$ & 16 Sept. 2003 & $12.10 \mathrm{ef}$ & $0.65 \mathrm{c}$ & $4.08 \mathrm{~d}$ \\
\hline 15 Sept. 2002 & $16.88 \mathrm{ef}$ & $0.71 \mathrm{~d}$ & $6.46 \mathrm{~d}$ & 12 Oct. 2003 & 12.89 ef & $0.79 \mathrm{bc}$ & $5.13 \mathrm{e}$ \\
\hline 27 Sept. 2002 & $17.75 \mathrm{ef}$ & $0.83 \mathrm{~d}$ & $8.70 \mathrm{e}$ & 30 Oct. 2003 & $13.65 \mathrm{f}$ & $0.76 \mathrm{c}$ & $6.26 \mathrm{f}$ \\
\hline 11 Oct. 2002 & $19.08 \mathrm{ef}$ & $1.37 \mathrm{~cd}$ & $10.5 \mathrm{ef}$ & & & & \\
\hline 25 Oct. 2002 & $19.71 \mathrm{f}$ & $0.63 \mathrm{~d}$ & $11.08 \mathrm{f}$ & & & & \\
\hline
\end{tabular}

${ }^{2}$ Numbers in each column are average root counts per viewing direction in a $45^{\circ}$ observational transect down through the root system equivalent to vertical depths of 50 and $56 \mathrm{~cm}$ in 2002 and 2003 (respectively). Values represent means of six or 18 observations per treatment or time in 2002 and 2003, respectively, with means separated by different letters at $P=0.05$.
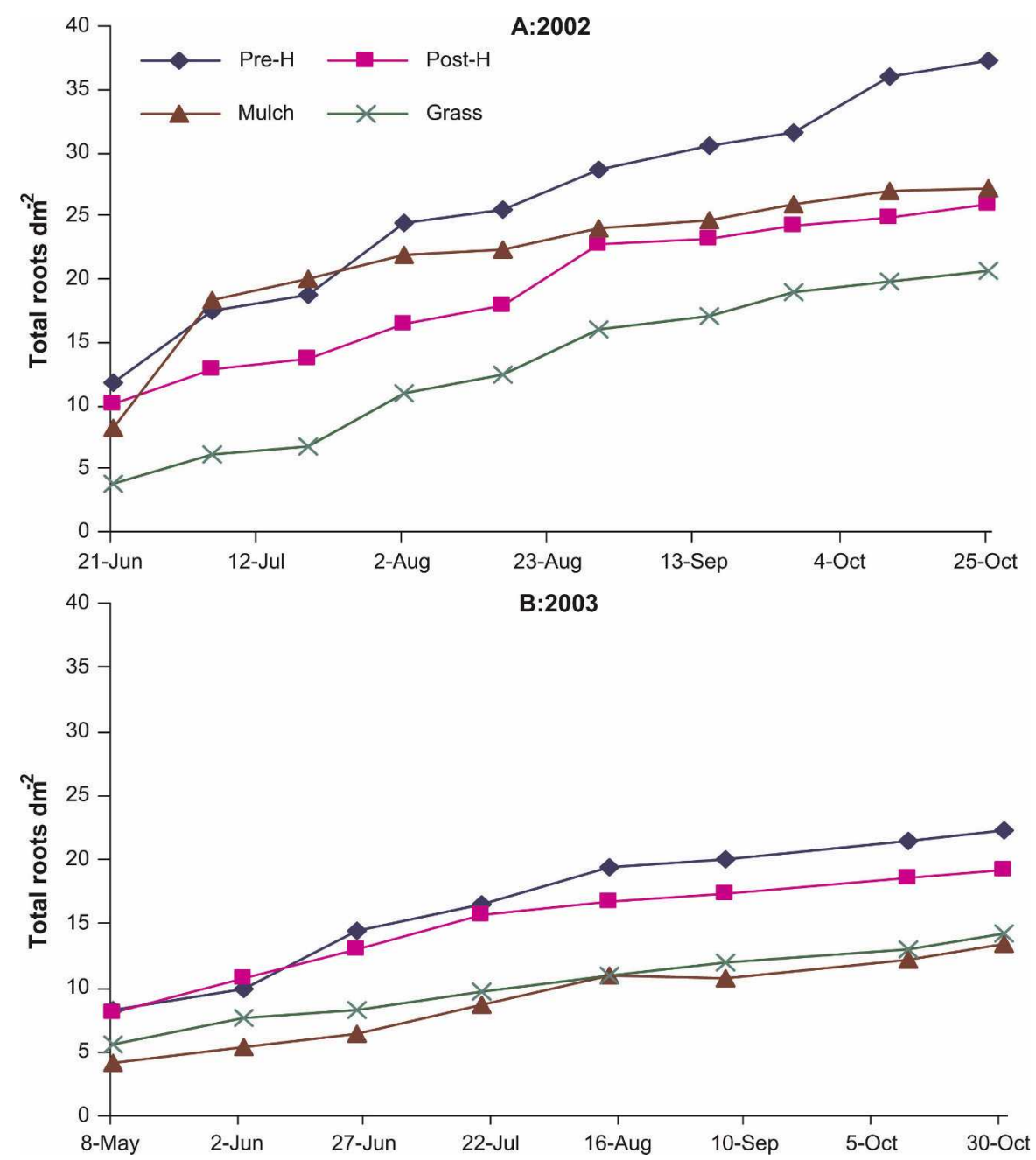

Fig. 1. Total cumulative root numbers (live and dead) of trees in four different groundcover management system (GMS) treatments in 2002 (A) and 2003 (B). Values are averages from two observation tubes beneath trees in each of three GMS replicates viewed in one direction in $2002(\mathrm{n}=6)$ and three directions in $2003(\mathrm{n}=18)$. treatments of glyphosate applied at a rate of 2 $\mathrm{kg} \cdot \mathrm{ha}^{-1}$ a.i. in mid-May and July each year; 3 ) mowed sod (Grass): Red fescue (Festuca rubra L.) turfgrass originally seeded in Sept. 1991 , now a mixture of $\approx 20$ grass and herbaceous broadleaf species mowed monthly during the growing season each year; and 4) bark mulch (Mulch): a 15-cm deep layer of shredded hardwood (Acer, Quercus, Juglans, Fraxinus, Tilia, and so on) composted bark mulch first applied in May 1992 and renewed every 2 years since then. After 1996, glyphosate herbicide was spot-applied in July each year during this study over $\approx 50 \%$ of the mulched area to suppress perennial weeds that became prevalent in this treatment. Three replicates of the four GMS treatments were randomly assigned to 12 large plots, each containing 20 to 24 trees. Detailed soil nutrient and microbial community information in each treatment were documented in recent reports (St. Laurent et al., 2008; Yao et al., 2005).

Minirhizotron installation. In July 2001, one tree near the center of each plot was selected for root study, and two transparent polycarbonate minirhizotron tubes with a diameter of $5 \mathrm{~cm}$ were diagonally inserted into holes bored into the root zone from opposite directions at a $45^{\circ}$ angle on either side of the tree, $\approx 40 \mathrm{~cm}$ from the trunk and approximately parallel to the tree row. The lengths of inserted tubes varied from 1.2 to $1.5 \mathrm{~m}$ (corresponding to observations down to $80 \mathrm{~cm}$ in vertical depth) because of the physical blockage by rocks in the soil at various locations. To allow for root recovery from soil disturbance during the boring and tube installation, no root observations were recorded in 2001. In 2002 and 2003, root images were taken at 2- to 3-week intervals during the growing season (May to October) with a BTC-2 minirhizotron system (Bartz Technology Corporation, Santa Barbara, CA). In 2002, only the vertical (upward toward the soil surface) direction on the cross-section of each tube was observed and the images started at 5-cm depth in the soil profile. Because the root numbers were often low and varied greatly among replicates in 2002, we tripled the observation sample size in 2003, recording images in three view angles: one vertical $\left(12\right.$ o'clock or $\left.0^{\circ}\right)$ in the tube cross-section, one at 3 o'clock $\left(90^{\circ}\right)$ toward the tree, and one in the middle of these two directions for each tube $\left(45^{\circ}\right)$.

The experimental interstem trees were planted with the upper scion-graft union at $4 \mathrm{~cm}$ aboveground, and the M.9 interstem pieces were $\approx 15 \mathrm{~cm}$ long so that $\approx 11 \mathrm{~cm}$ of the interstem shank was belowground and developed lateral roots on each tree. Therefore, our root observations included lateral roots from both the upper M.9 interstem portion and the lower MM.111 portion of each root system.

Whole tree excavation. As part of a previous study of $15-\mathrm{N}$ isotope partitioning into different parts of apple trees in each GMS, in Apr. 2000, we unearthed and dissected one entire tree from each plot, taking precautions 

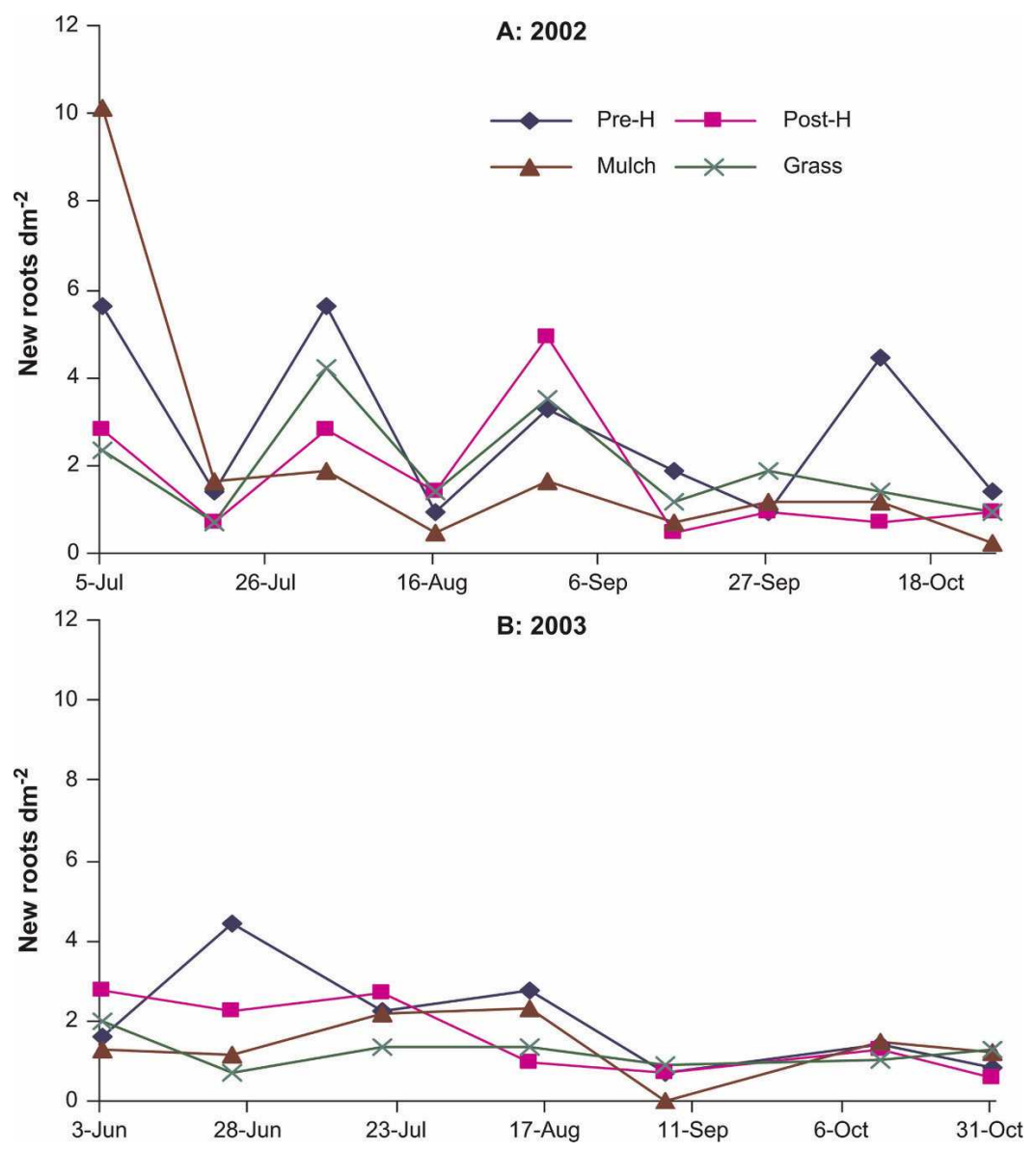

Fig. 2. New root emergence observed for trees in four groundcover management system (GMS) treatments during the growing seasons of 2002 and 2003. Values are averages of two observation tubes beneath trees in each of three GMS replicates viewed in one direction in $2002(\mathrm{n}=6)$ and three directions in $2003(\mathrm{n}=18)$
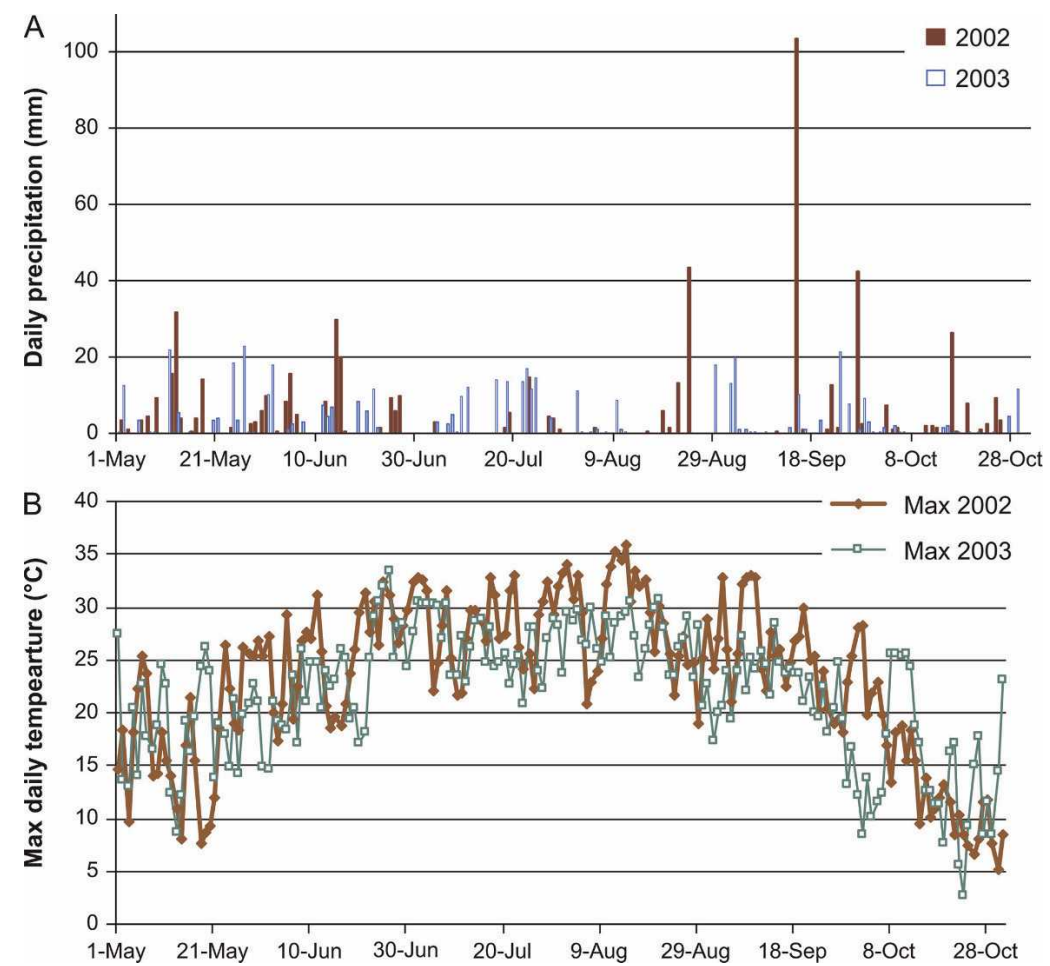

Fig. 3. Maximum daily rainfall (A) and ambient temperatures (B) at the experimental site during the growing seasons of 2002 and 2003. to conserve as much of the fine root system as possible. The soil was moist but friable during this sampling. Trees were lifted during the process, and we did not map their horizontal or vertical root distribution during excavation because the objective was to determine root dry weight and $15-\mathrm{N}$ allocations to different root diameter categories. As much of each root system as possible was manually extracted from the soil with hand picks and trowels, massaged and shaken gently to remove adherent soil, and then divided into separate cohorts based on root diameter and hierarchical position. Each root size cohort was weighed fresh and then ovendried for determination of dry weight biomass for the main rootstock shank, lateral main roots ( 1 to $4 \mathrm{~cm}$ in diameter), secondary roots $(1 \mathrm{~mm}$ to $1 \mathrm{~cm})$, and fine roots (less than $1 \mathrm{~mm})$.

Tree performance. Tree growth was estimated as trunk cross-sectional area (TCSA), and yield data ( $\mathrm{kg}$ fruit per tree) were collected annually from 1992 to 2004 .

Soil temperature and water content. Soil water content (volumetric basis) was monitored year round from 0 - to $20-\mathrm{cm}$ depth with datalogged dielectric time-domain reflectometry probes (Campbell Scientific, Logan, UT) inserted midpoint between two trees near the center of each plot. Soil temperatures were monitored with bimetallic thermoelectric resistors at 5- and 20-cm depth in each plot. Lightning strikes disabled the soil water and temperature dataloggers several times during the course of this study, so these observations were not entirely continuous during the study.

Data analyses. All root images were recorded digitally at the time of observations and then analyzed with RooTracker software (RooTracker®; Duke University, Durham, NC) marking the root length, diameter, position, depth, first appearance date, and disappearance date. Roots on their first appearance dates were marked as new roots and on their disappearance date were tabulated as dead. From these observations, we calculated the total root number, new root emergence, root survivorship, size and depth distribution, and root lifespan. Trends over time and among GMS treatments for total root numbers, live roots, and root mortality were analyzed with analysis of variance as a repeated measures model after natural logarithm $(x+1)$ transformation with significant differences inferred at $P=0.05$ (Analytical Software Statistix 7.0, Tallahassee, FL). Root survivorship was analyzed with Cox proportional hazards regression model (Wells and Eissenstat, 2001). The data for root diameter and overwintering survival of different root branching orders were combined from all treatments for regression analyses because of low root counts per tree.

\section{Results}

Total root counts across all treatments in 2002 and 2003. Despite the high variability among replicates, GMS treatment had 


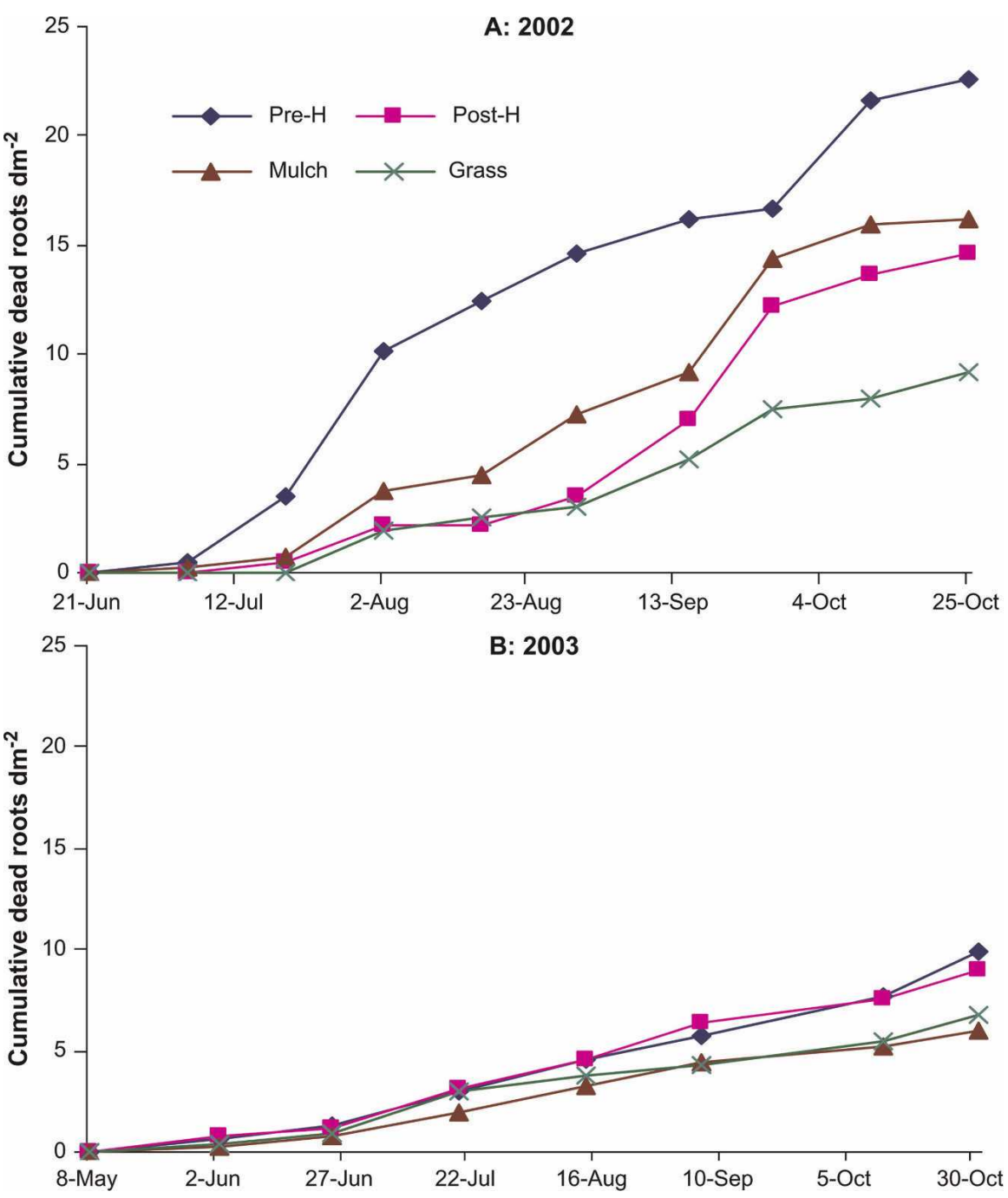

Fig. 4. Cumulative dead root numbers in four groundcover management system (GMS) treatments during the growing seasons of 2002 (A) and 2003 (B). Values are averages of two observation tubes beneath trees in each of three GMS replicates viewed in one direction in $2002(n=6)$ and three directions in $2003(\mathrm{n}=18)$

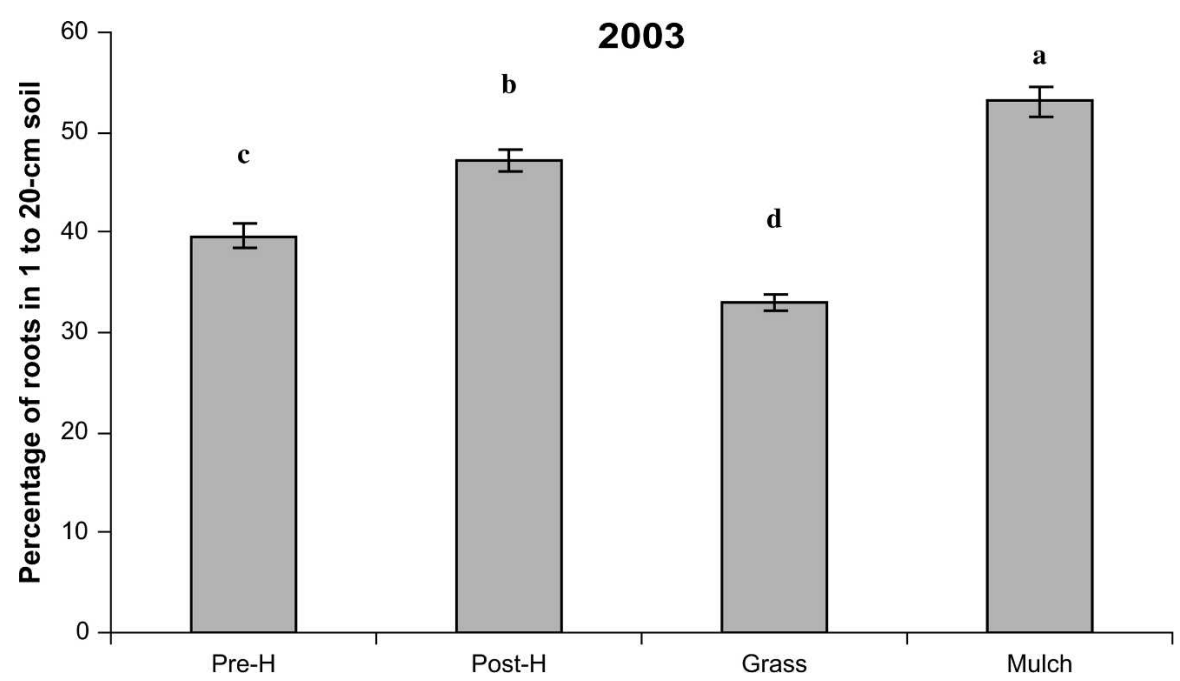

Fig. 5. Average percentages of roots observed in the 1- to $20-\mathrm{cm}$ soil profile beneath trees in each groundcover management system treatment during the growing season of 2003. Averages are based on eight root observation sessions in that growing season (mean $\pm \mathrm{SE}$ ). Different letters indicate mean separations at $P=0.05$. significant effects on total root counts in both 2002 and 2003, and the time effects were also significant (Table 1; Fig. 1). Total root counts in the four GMS treatments ranked Pre-H > Mulch $>$ Post-H $>$ Grass in 2002 and Pre-H $>$ Post-H $>$ Grass $>$ Mulch in 2003. Cumulative root numbers (new + previous + dead) were higher in 2002, a light cropload year resulting from bloom-time frost damage, than in 2003, a heavy cropload year (Fig. 1A-B).

New root appearance over time. New root emergence continued intermittently throughout the growing seasons of 2002 and 2003 (Fig. 2), but the patterns of new root emergence in 2002 (Fig. 2A) were different from those in 2003 (Fig. 2B). Trees in the Pre-H treatment produced more new roots than those in other GMSs during 2002. In 2003, the Pre-H trees produced more new roots than Grass and Mulch treatments, and there were no differences among Post- $\mathrm{H}$, Grass, and Mulch treatments. During 2002, new root emergence peaked during late July and August, after heavy rains at the end of a relatively dry period earlier that summer (Table 1; Figs. 2A and 3A). With greater fruit load on trees in 2003, their new root emergence was reduced but was also more uniform over time than in 2002 (Fig. 2B). There were more new roots in early summer compared with late summer of 2003 (Table 1; Fig. 2B)

Episodic and cumulative root mortality. Root mortality at the beginning of the growing season was minimal in all GMSs during both 2002 and 2003 (Fig. 4). There was an episode of relatively high root mortality in early August of 2002 for all GMS treatments following 6 weeks of hot, dry weather during June and July that year (Fig. 3). Observed root mortality was greater in Pre-H plots during that drought period in 2002 despite microsprinkler irrigation equivalent to $2 \mathrm{~cm}$ of water per week (Fig. 4A). The Pre-H treatment had more root mortality than all other treatments, with mortality ranking Pre- $\mathrm{H}>$ Mulch $>$ Post-H $>$ Grass. The overall trends in root mortality were complex and variable among treatments in 2002. The following year was abnormally cool and wet throughout the growing season, and the trees were heavily cropped. There was less root mortality in all four GMSs during 2003 than 2002. The mortality rates were similar among GMS treatments and remained relatively uniform among all four GMSs throughout the 2003 growing season. However, at the end of Oct. 2003, trees in Pre-H and Post-H plots had higher cumulative root mortality compared with Mulch and Grass (Fig. 4B; Table 1)

Root depth distribution. There were differences in the percentages of roots occurring in the topsoil (1 to $20 \mathrm{~cm}$ deep) profile among GMS treatments during 2003, ranked in decreasing order as Mulch $>$ Post-H $>$ Pre$\mathrm{H}>$ Grass (Fig. 5). Root-depth distribution over 5-cm increments also differed among the GMS treatments and between the two growing seasons (data not shown). Trees in the Mulch treatment had relatively more 


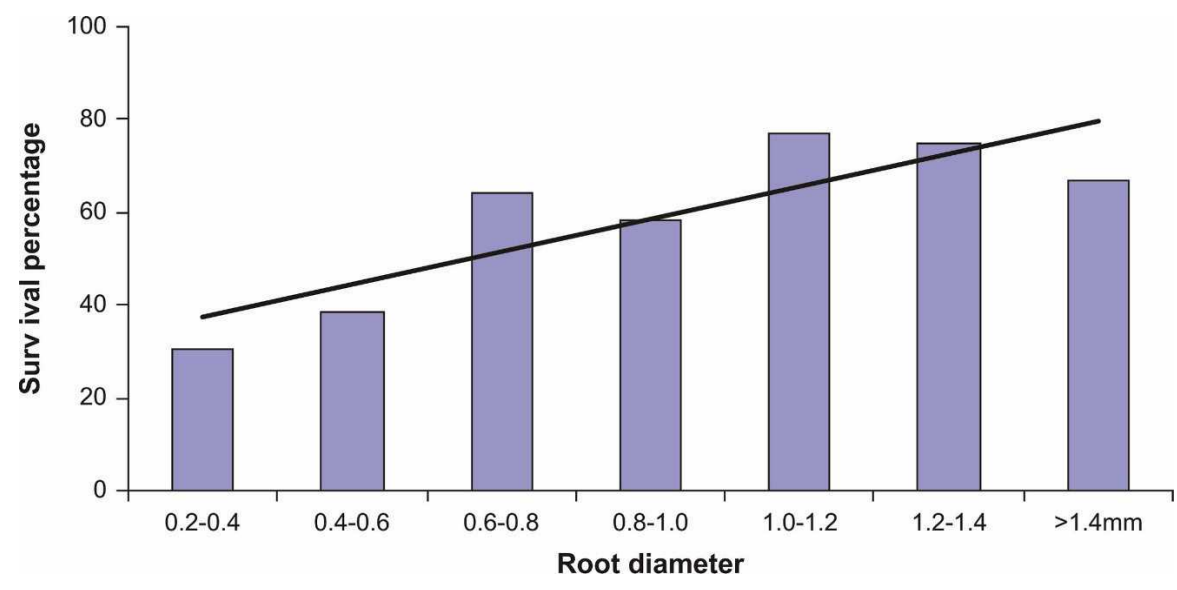

Fig. 6. Overwintering root survival among various root diameter categories between 5 Nov. 2002 and 20 Apr. 2003. Sample is combined for all groundcover management system treatments. The superimposed line across diameters represents the linear fit $\left(r^{2}=0.83, P=0.05\right)$ between root diameter and overwinter survival.

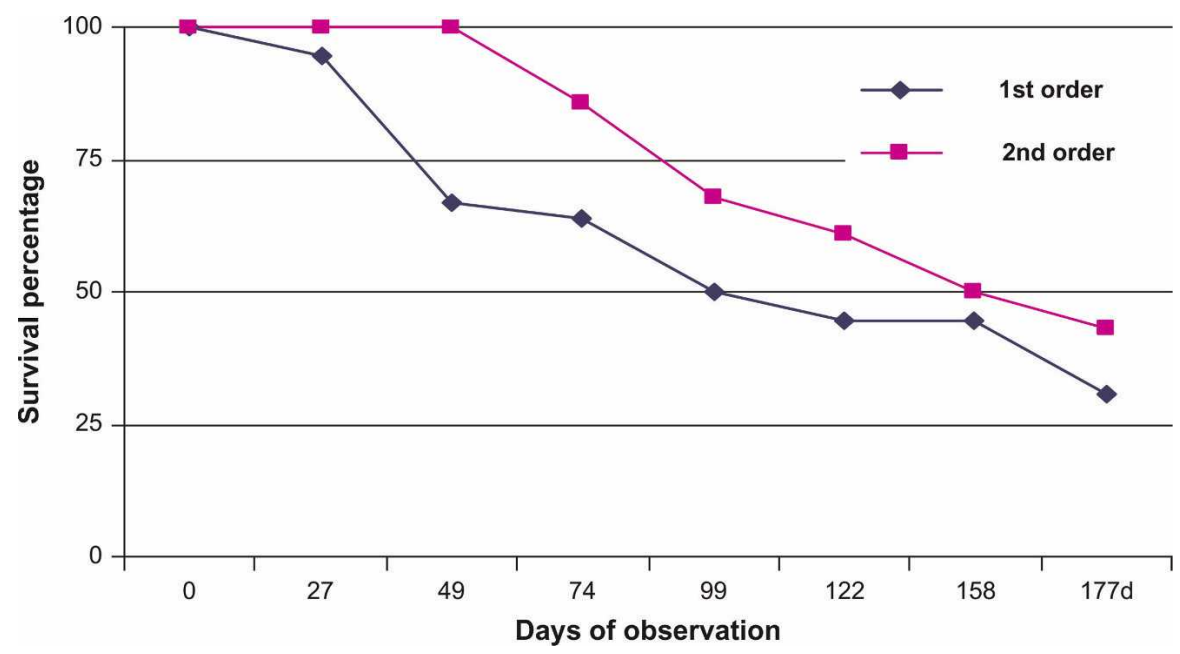

Fig. 7. Cumulative mortality of first and second-order roots during 2002. First-order roots were distal from and second-order roots were proximal to the original parent roots. The observational cohort represented all roots present on 8 May 2003 and then monitored biweekly for $177 \mathrm{~d}$.

shallow (from 1 to $10 \mathrm{~cm}$ depth) roots than trees growing in the other treatments, and those in the Grass plots had fewer shallow roots in both years. Trees in the Pre-H and Post-H treatments had more roots in the 10to $20-\mathrm{cm}$ range than those in the Mulch and Grass treatments. Root counts at various depths were also more variable in 2002 than 2003 and were nonuniform among treatments in both years.

Root diameter and survival. Increased root diameter was positively correlated with overwintering root survival $\left(r^{2}=0.83, P=\right.$ 0.05 ) during the winter of 2002-03 (Fig. 6). Larger diameter roots had higher overwintering survival rates than smaller roots.

Survival of roots of different branching orders. Median root lifespan (the time elapsed when $50 \%$ of roots died within each positional cohort) of first-order (the most distal roots observed) small feeder roots was shorter (99 d) than the median lifespan (158 d) for older (second order) parent roots on which lateral first-order roots originated in 2002 (Fig. 7).
Root lifespan comparisons between years and among groundcover management system treatments. The median root lifespan for trees in all GMS treatments was shorter in 2002 (40 to $90 \mathrm{~d}$ ) than in 2003 (100 to $180 \mathrm{~d}$ ) (Fig. 8). Pre-H tree roots had median lifespans shorter than those of Post-H roots during 2002, but this trend was not sustained in 2003.

Tree root biomass allocations. For excavated tree root systems in April of 2000, there was more fine feeder-root biomass (less than 1 $\mathrm{mm}$ diameter) in the Mulch, Pre-H, and Post$\mathrm{H}$ plots compared with tree roots in the Grass treatment (Fig. 9). However, root biomass for the midsize cohort (1 to $10 \mathrm{~mm}$ ) was greater in the Mulch than in Pre-H and Grass treatments. Most of the fine feeder roots in Mulch plots were concentrated vertically within a partially decomposed humus layer $(\approx 2 \mathrm{~cm}$ thick $)$ between the Mulch material and the underlying mineral soil. Although we excavated roots down to $60 \mathrm{~cm}$ below the soil surface, relatively few roots were observed below $35-\mathrm{cm}$ depth for any of the 12 tree-root systems.
Tree growth and yields. Trunk crosssectional areas at $40 \mathrm{~cm}$ above the upper graft union of trees grown after 11 years in each GMS treatment were $\approx 15 \%$ greater in the Mulch and Post-H treatments compared with the trees in Grass and Pre-H treatments (data not shown). Substantial differences in fruit yields were observed among trees in the GMSs during some years of this long-term study, including 2001 and 2003, but yield trends varied over the years (Fig. 10). Trees in the Grass plots were the least productive in most years. Yield was reduced substantially and did not differ among treatments during 2002 after a hard frost during bloom. During 2003, yield was greater on trees in the Post-H treatment compared with those in the Grass treatment and similar in the Pre-H and Mulch treatments. Yield efficiency ( $\mathrm{kg}$ fruit per unit TCSA) was often lower for the more vigorous trees in Mulch compared with other treatments (data not shown).

\section{Discussion}

For tree root studies, the high variability in root distribution and consequent need for high sample numbers to reduce experimental error are persistent challenges (Eissenstat and Yanai, 1997). Although apple root density is reportedly greater near the tree base (Atkinson, 1980), we observed surprisingly few roots per tree in our study, even with two observation tubes located as close to trees as possible without access interference from lower tree branches. Low root counts contributed to high variability among replicates of the same treatment and made statistical differentiation among treatments a problem in this study, like in many others (Eissenstat and Yanai, 1997; Yao et al., 2006). Despite these problems, this study provides information on the relationship between orchard GMSs and tree root demography and dynamics about which little has been reported previously.

New root emergence and root mortality in relation to environmental factors. Unusually hot and dry weather from mid-June to midSept. 2002 affected root growth and mortality despite weekly microsprinkler irrigation during that drought. In mid-Summer 2002, there were $20 \mathrm{~d}$ with maximum temperatures over $32{ }^{\circ} \mathrm{C}$ compared with just $1 \mathrm{~d}$ in that temperature range for the entire growing season of 2003 (Fig. 3B). Average ambient temperatures for July and Aug. 2002 were 1.0 and $1.3{ }^{\circ} \mathrm{C}$ higher, respectively, than for the same period in 2003. These climate conditionshigh temperatures and infrequent rainfallappeared to suppress new root emergence and increase root mortality in the summer of 2002. During the hottest months of 2002, soil temperature data were lost when lightning damaged our main datalogger. However, records from earlier and later years at this site indicate that soil temperatures at $5-\mathrm{cm}$ depth range from 20 to $25^{\circ} \mathrm{C}$ and average 2 to $4{ }^{\circ} \mathrm{C}$ warmer in the weed-free soil of Pre- $\mathrm{H}$ and Post-H plots compared with Grass and Mulch plots during midsummer, except 

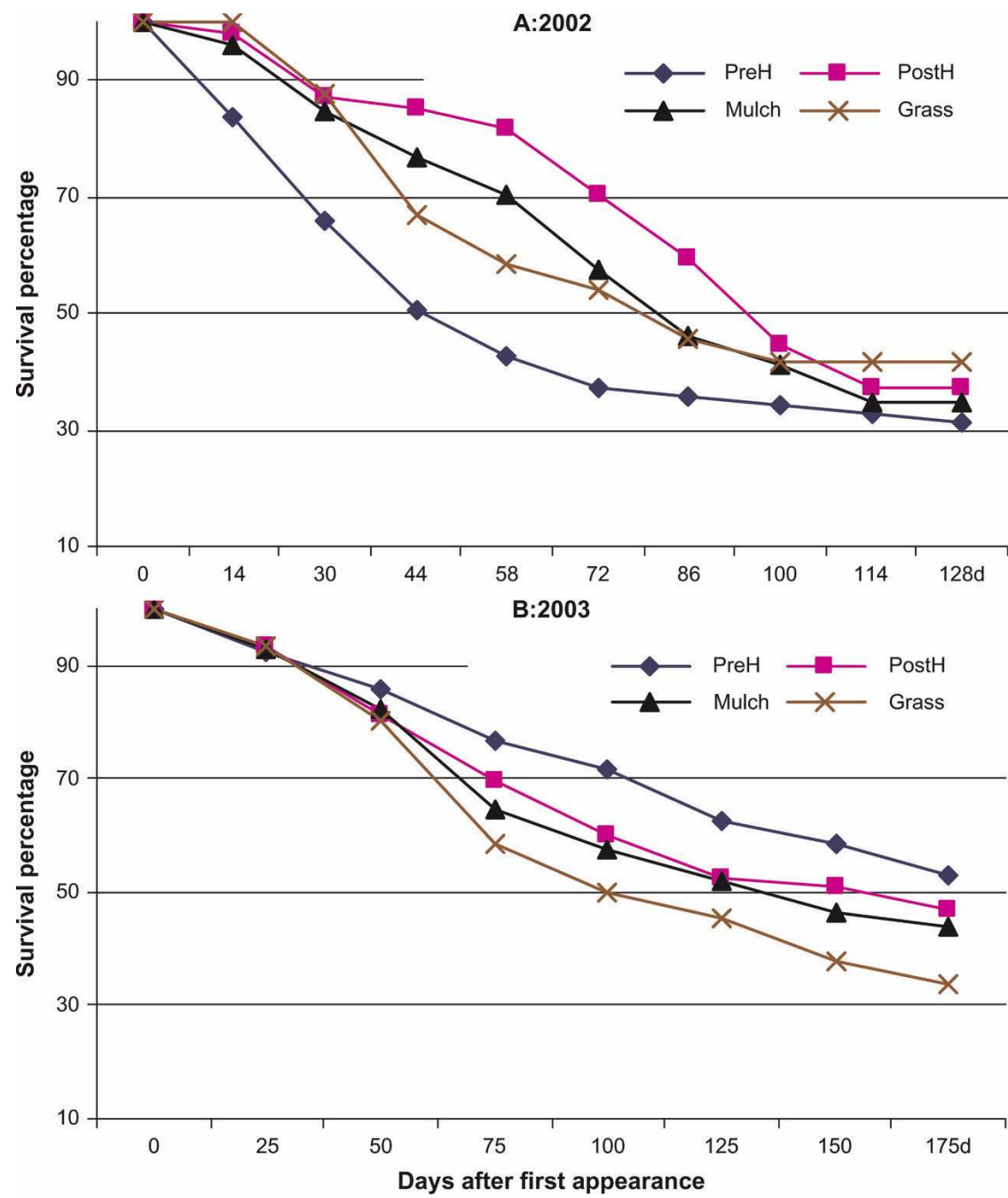

Fig. 8. Subsequent survival of the initial root cohorts from late June onward in 2002 (A) and early June onward in 2003 (B). Values are averages of two observation tubes beneath trees in each of three groundcover management system replicates viewed in one direction in $2002(\mathrm{n}=6)$ and three directions in $2003(\mathrm{n}=18)$.

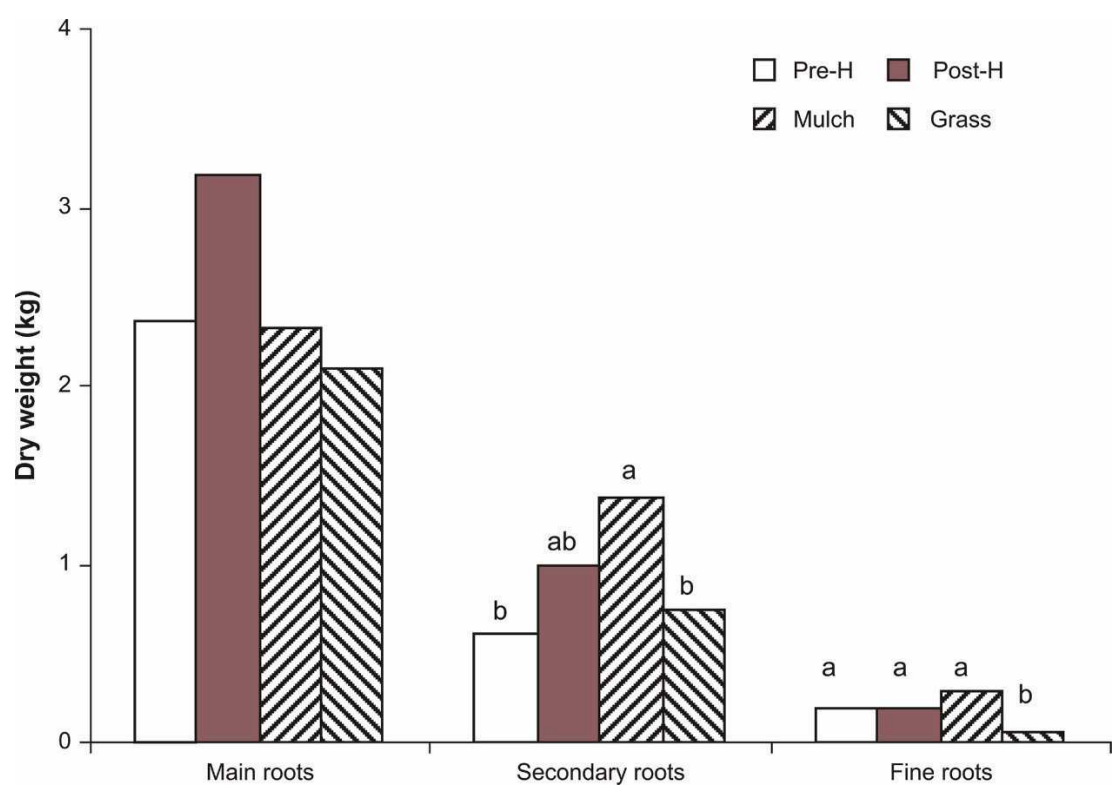

Fig. 9. Dry weight biomass distribution among various root size categories (main roots were 1 to $4 \mathrm{~cm}$; secondary roots $1 \mathrm{~mm}$ to $1 \mathrm{~cm}$; and fine roots less than $1 \mathrm{~mm}$ in diameter) based on whole-tree root excavations in four groundcover management system treatments during Apr. 2000. Different letters indicate significant differences $(P=0.05)$ among the means of three treatment replications. during cool and cloudy days (data not shown). In 2003, when precipitation was more evenly distributed and average temperatures were cooler, new root growth was sustained for most of the growing season at this orchard.

Other research has also shown that midsummer temperatures are warmer in the upper layer of soil kept weed-free with residual herbicide treatments, which is more directly exposed and absorptive to solar radiation (Hogue and Neilsen, 1987; Merwin et al., 1994). Tukey (1983) reported that Malling apple rootstocks often perform poorly in regions where the growing season is much hotter than in the United Kingdom or the northeastern United States. Even in a relatively cool humid region such as upstate New York, the upper soil profile in weed-free herbicide plots may become hot enough to reduce apple root growth and survival.

There are relatively few and inconsistent reports concerning the relationship between tree root growth and environmental factors. Psarras and Merwin (2000) reported that M.9 and MM.111 apple rootstock growth, morphology, and respiration rates were affected strongly by soil water potential. Other studies have also shown correlations between fine root growth and environmental factors (Davis et al., 2004; Kuhns et al., 1985; Steele et al., 1997). Fine root growth was positively correlated with soil temperatures at $10-\mathrm{cm}$ depth for aspen (Populus tremuloides Michx.), jack pine (Pinus banksiana Lamb.), and black spruce [Picea mariana (Mill.) BSP] in research carried out in Canada (Steele et al., 1997). Tierney et al. (2003) reported that in a northern hardwood forest, fine root production of sugar maple (Acer saccharum Marsh.) and yellow birch (Betula alleghaniensis Brit.) was positively associated with ambient air temperature. Kuhns et al. (1985) demonstrated that roots of black walnut (Juglans nigra L.) began growth at $4{ }^{\circ} \mathrm{C}$, with growth rates and root emergence peaking around $20{ }^{\circ} \mathrm{C}$, the highest temperature they observed in moist soils of that study. However, Tierney et al. (2003) noted that sugar maple root growth peaked at $17{ }^{\circ} \mathrm{C}$ and that both root growth rates and the number of actively growing roots dropped sharply as soil water potential dropped from -0.5 to $-1.0 \mathrm{MPa}$.

Several other researchers have reported minimal environmental influences on root growth and concluded that fine root demographics and dynamics are endogenously regulated (Cote et al., 1998; Hendrick and Pregitzer, 1997). There may be fundamental differences between fruit trees and forest tree species in this regard because of orchard factors such as use of clonal rootstocks, heavy croploads, and intensive management inputs. Nonetheless, our results indicate that apple root emergence and mortality are sensitive to drought and heat stress, even with supplemental irrigation.

Root median lifespan, cropload, and environmental conditions. In a comparable minirhizotron study at a nearby apple replant site, new root emergence was greater in a 


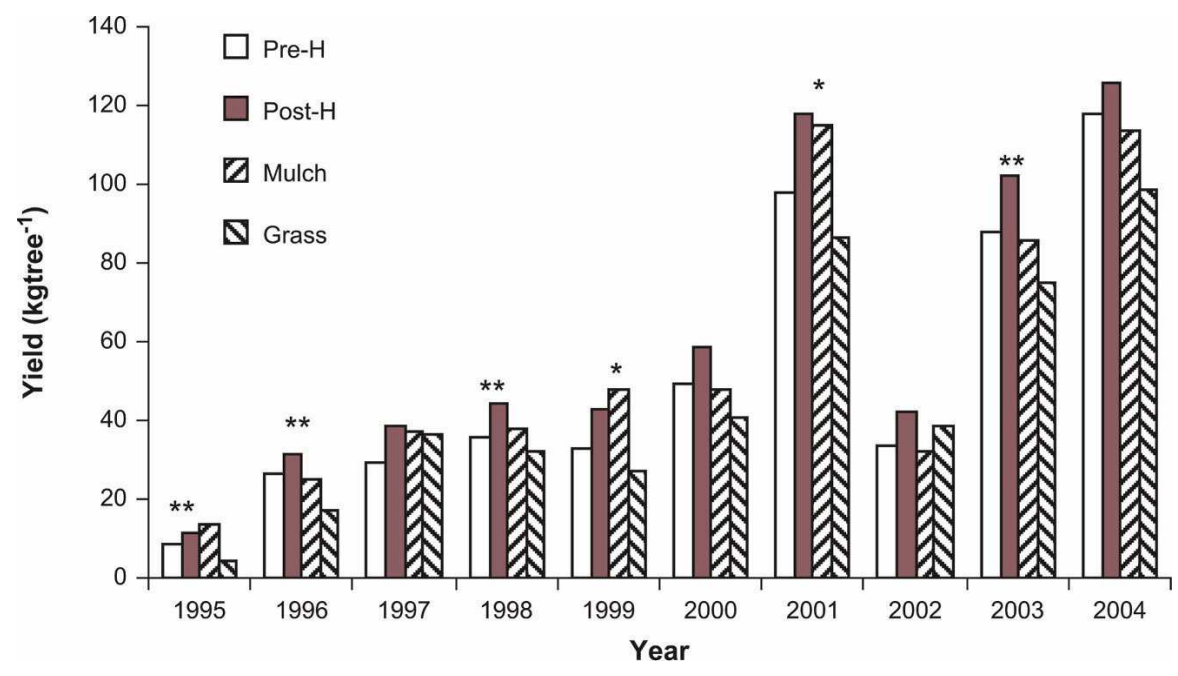

Fig. 10. Cumulative average yields ( $\mathrm{kg}$ fruit per tree) of trees grown in four groundcover management system (GMS) treatments from 1995 to 2004. Yields in 2002 were reduced substantially by a frost during bloom. Asterisks above each yearly group represent significant differences among yields in GMSs during that year at $P=0.10(*)$ or $P=0.05(* *)$ for three replications of each treatment.

nonbearing versus heavy cropload year, and the root median lifespan for roots of CG.6210 rootstocks supporting heavy crops was much longer than that of the rootstocks of G.30 and M.7 trees with light crops (Yao et al., 2006). Palmer (1992) reported that increased cropload of 'Mutsu' on M.27 rootstock decreased tree dry matter partitioning to root biomass. In our study, new root growth was inhibited and existing roots survived longer during a heavy crop year than a light crop year, but heat stress during 2002 may have interacted with cropload effects influencing root growth.

Eissenstat and Yanai (1997) found that roots of native plants in the field survived longer and tended to exhibit lower mortality rates over winter in cooler environments. Hendrick and Pregitzer (1993) reported that roots of sugar maple lived $\approx 75 \mathrm{~d}$ longer at a cooler site than at a relatively warmer site. They suggested that direct respiratory maintenance and indirect higher activity of root pathogens and nitrogen mineralization at warmer temperatures could affect median root lifespan. Hayes and Seastedt (1987) reported that root mortality of big bluestem (Andropogon gerardii) was high during drought but that mortality rates were fairly constant in the following year when no drought occurred. Our results - higher root mortality in the dry and hot year (2002) and lower mortality in the cool and wet year (2003) - were consistent with these other reports. Median root lifespan appears to vary according to rootstock genotype, cropload, resistance or tolerance to root pathogens, soil temperature and moisture conditions, and other environmental factors (Yao et al., 2006).

Root depth distribution and groundcover management system treatments. Comparing the minirhizotron observations during 2002 and 2003 with the root excavation observations at this orchard 2 years earlier, the trends were fairly consistent. Both experimental approaches indicated that trees in Mulch had more shallow roots, and trees in Grass had more deep roots, compared with trees in the two herbicide GMS treatments, as reported previously by Atkinson (1980). Favorable soil conditions such as increased soil organic matter, greater cation exchange capacity, higher rates of soil microbial respiration, and disease-suppressive soil microflora apparently promote tree root growth under mulch (Yao et al., 2005). In contrast, grass roots compete with apple roots for soil nutrients and water and may indirectly cause tree roots to proliferate deeper in the soil profile (Giovannini et al., 2001; Hogue and Neilsen, 1987).

In Pre-H plots with negligible surface vegetation during the summer months, herbicide residues can accumulate and soil physical conditions may deteriorate over time, eventually becoming unfavorable for root growth near the surface (Merwin et al., 1994; Oliveira and Merwin, 2001). However, the Pre-H trees had the highest total root counts among our four GMS treatments (Table 1; Figs. 1 and 2). Other studies have reported similar results for peach and apple orchards with more tree roots (from excavation or transect observations) observed in mulch or herbicide-treated plots than in cover-crop treatments (Parker et al., 1993; Parker and Meyer, 1996; Stefanelli and Perry, 2006). One difference between transect and minirhizotron studies may be that observable shallow surface roots can be suppressed by light penetration around the tube surface or reduced upper tube-soil surface contact from successive observations.

Root diameter and root survival. Root survival was correlated with root diameter, and second-order roots lived longer than more distal first-order roots. Wells and Eissenstat (2001) also reported that overwinter- ing survival differed markedly among roots of different diameters, with roots greater than $0.5 \mathrm{~mm}$ in diameter more likely to survive over winter than those less than $0.5 \mathrm{~mm}$ in diameter. Minirhizotrons are unlikely to affect fine root longevity and may provide reliable measurements of fine root production (Tierney and Fahey, 2001), but it is difficult to determine the observed root hierarchy in planar minirhizotron images. Some fine roots can be seen in their entirety as they extend along the tube surface; but for most others, the observed image reveals only one or several root segments of uncertain rank. To avoid this uncertainty, we considered only parent roots and their observed branches as second- and first-order roots (respectively), but this approach was likely to underestimate the number of second-order roots.

Over the past decade, trees in the Grass treatment have produced consistently lower yields than those in the other three GMS treatments, whereas trees in Post-H and Mulch treatments have usually been the most productive. After 11 years, the GMS treatments in our study led to substantially different soil physical conditions, root-zone microbial communities, root depth distributions, and root demographics. These belowground GMS impacts have influenced tree growth and productivity as well as root depth, survival, and biomass partitioninglong-term trends with implications for the sustainability of orchards under different GMSs.

\section{Literature Cited}

Atkinson, D. 1980. The distribution and effectiveness of the roots of tree crops. Hort. Rev. (Amer. Soc. Hort. Sci.) 2:424-490.

Atkinson, D. and G.C. White. 1976. The effect of the herbicide strip system of management on root growth of young apple trees and the soil zones from which they take up mineral nutrients. Rpt. East Malling Res. Sta. 1975: 165-197.

Cote, B., W.H. Hendershot, J.W. Fyles, A.G. Roy, R. Bradley, P.M. Biron, and F. Courchesne. 1998. The phenology of fine root growth in a maple-dominated ecosystem: Relationships with some soil properties. Plant Soil 201:5969.

Davis, J.P., B. Haines, D. Coleman, and R. Hendrick. 2004. Fine root dynamics along an elevational gradient in the southern Appalachian Mountains, USA. For. Ecol. Mgt. 187:19-34.

Eissenstat, D.M., C.E. Wells, R.D. Yanai, and J.L. Whitbeck. 2000. Building roots in a changing environment: Implications for root longevity. New Phytol. 147:33-42.

Eissenstat, D.M. and R.D. Yanai. 1997. The ecology of root lifespan, p. 1-60. In: Bergon, M and A.H. Fitter (eds.). Advances in ecological research. Vol 27. Academic Press Ltd., London, UK.

Garland, J.L. and A.L. Mills. 1991. Classification and characterization of heterotrophic microbial communities on the basis of patterns of community-level sole-carbon-source utilization. Appl. Environ. Microbiol. 57:2351-2359.

Giovannini, D., D. Scudellari, A. Aldini, and B. Marangoni. 2001. Soil management in an organic peach orchard. Rivista di Frutticoltura e di Ortofloricoltura 63:21-29. 
Glenn, D.M. and W.V. Welker. 1989. Peach root development and tree hydraulic resistance under tall fescue sod. HortScience 24:117119.

Goh, K.M., D.R. Pearson, and M.J. Daly. 2001. Effects of apple orchard production systems on some important soil physical, chemical and biological quality parameters. Biol. Agr. Hort. 18:269-292.

Hayes, D.C. and T.R. Seastedt. 1987. Root dynamics of tallgrass prairie in wet and dry years. Can. J. Bot. 65:787-791.

Hendrick, R.L. and K.S. Pregitzer. 1992. The demography of fine roots in a northern hardwood forest. Ecology 73:1094-1104.

Hendrick, R.L. and K.S. Pregitzer. 1993. Patterns of fine root mortality in 2 sugar maple forests. Nature 361:59-61.

Hendrick, R.L. and K.S. Pregitzer. 1997. The relationship between fine root demography and the soil environment in northern hardwood forests. Ecoscience 4:99-105.

Hogue, E.J. and G.H. Neilsen. 1987. Orchard floor vegetation management. Hort. Rev. (Amer. Soc. Hort. Sci.) 9:377-430.

Kuhns, M.R., H.E. Garrett, R.O. Teskey, and T.M. Hinckley. 1985. Root-growth of black walnut trees related to soil-temperature, soil-water potential, and leaf water potential. Forest Sci. 31:617-629.

Merwin, I.A. 2003. Orchard-floor management systems, p. 303-318. In: Ferree, D.C. and I.J. Warrington (eds.). Apples-Botany, production and uses. CABI Publishing, Wallingford, UK.

Merwin, I.A., J.A. Ray, T.S. Steenhuis, and J. Boll. 1996. Groundcover management systems influence fungicide and nitrate- $\mathrm{N}$ concentrations in leachate and runoff from a New York apple orchard. J. Amer. Soc. Hort. Sci. 121:249257.

Merwin, I.A. and W.C. Stiles. 1994. Orchard groundcover management impacts on apple tree growth and yield, and nutrient availability and uptake. J. Amer. Soc. Hort. Sci. 119:209215.

Merwin, I.A., W.C. Stiles, and H.M. Vanes. 1994. Orchard groundcover management impacts on soil physical properties. J. Amer. Soc. Hort. Sci. 119:216-222.
Neilsen, D., P. Millard, L.C. Herbert, G.H. Neilsen, E.J. Hogue, P. Parchomchuk, and B.J. Zebarth. 2003a. Remobilization and uptake of $\mathrm{N}$ by newly planted apple (Malus domestica) trees in response to irrigation method and timing of $\mathrm{N}$ application. Tree Physiol. 21:513-521.

Neilsen, G.H., E.J. Hogue, T. Forge, and D. Neilsen. 2003b. Mulches and biosolids affect vigor, yield and leaf nutrition of fertigated high density apple. HortScience 38:41-45.

Oliveira, M.T. and I.A. Merwin. 2001. Soil physical conditions in a New York orchard after eight years under different groundcover management systems. Plant Soil 234:233-237.

Palmer, J.W. 1992. Effects of varying crop load on photosynthesis, dry matter production and partitioning of Crispin/M.27 apple trees. Tree Physiol. 11:19-33.

Parker, M.L., J. Hull, and R.L. Perry. 1993. Orchard floor management affects peach rooting. J. Amer. Soc. Hort. Sci. 118:714-718.

Parker, M.L. and J.R. Meyer. 1996. Peach tree vegetative and root growth respond to orchard floor management. HortScience 31:330333.

Pedersen, H.L. 1997. Alleyway groundcover management impacts on soil, pests and yield components in blackcurrants (Ribes nigrum L). Biol. Agr. Hort. 14:159-169.

Psarras, G. and I.A. Merwin. 2000. Water stress affects rhizosphere respiration rates and root morphology of young 'Mutsu' apple trees on M.9 and MM.111 rootstocks. J. Amer. Soc. Hort. Sci. 125:588-595.

Psarras, G., I.A. Merwin, A.N. Lakso, and J.A. Ray. 2000. Root growth phenology, root longevity, and rhizosphere respiration of field grown 'Mutsu' apple trees on 'Malling 9' rootstock. J. Amer. Soc. Hort. Sci. 125:596602.

Reid, J.B., I. Sorensen, and R.A. Petrie. 1993. Root demography in kiwifruit (Actinidia-Deliciosa). Plant Cell Environ. 16:949-957.

St. Laurent, A., I.A. Merwin, and J.E. Thies. 2008. Long-term orchard groundcover management systems affect soil microbial communities and apple replant disease severity. Plant Soil 304:209-225.

Steele, S.J., S.T. Gower, J.G. Vogel, and J.M. Norman. 1997. Root mass, net primary pro- duction and turnover in aspen, jack pine and black spruce forests in Saskatchewan and Manitoba, Canada. Tree Physiol. 17:577587.

Stefanelli, D. and R.L. Perry. 2006. Effect of ground floor management systems on root architecture of Pacific Gala on M.9 NAKB 337 under organic management. HortScience 41:997.

Tierney, G.L. and T.J. Fahey. 2001. Evaluating minirhizotron estimates of fine root longevity and production in the forest floor of a temperate broadleaf forest. Plant Soil 229:167-176.

Tierney, G.L., T.J. Fahey, P.M. Groffman, J.P. Hardy, R.D. Fitzhugh, C.T. Driscoll, and J.B. Yavitt. 2003. Environmental control of fine root dynamics in a northern hardwood forest. Glob. Change Biol. 9:670-679.

Tukey, H.B. 1983. Dwarfed fruit trees-For orchard, garden, and home. With special reference to the control of tree size and fruiting in commercial fruit production. Comstock Publishing Associates, Ithaca, NY, and London, UK.

Tworkoski, T.J. and D.M. Glenn. 2001. Yield, shoot and root growth, and physiological responses of mature peach trees to grass competition. HortScience 36:1214-1218.

Walsh, B.D., A.F. MacKenzie, and D.J. Buszard. 1996. Soil nitrate levels as influenced by apple orchard floor management systems. Can. J. Soil Sci. 76:343-349.

Wells, C.E. and D.M. Eissenstat. 2001. Marked differences in survivorship among apple roots of different diameters. Ecology 82:882-892.

Wells, C.E., D.M. Glenn, and D.M. Eissenstat. 2002. Changes in the risk of fine-root mortality with age: A case study in peach, Prunus persica (Rosaceae). Amer. J. Bot. 89:79-87.

Werner, M.R. 1997. Soil quality characteristics during conversion to organic orchard management. Appl. Soil Ecol. 5:151-167.

Yao, S., I.A. Merwin, G.W. Bird, G.S. Abawi, and J.E. Thies. 2005. Orchard floor management practices that maintain vegetative or biomass groundcover stimulate soil microbial activity and alter soil microbial community composition. Plant Soil 271:377-389.

Yao, S., I.A. Merwin, and M.G. Brown. 2006. Root dynamics of apple rootstocks in a replanted orchard. HortScience 41:1149-1155. 